\title{
The Concept of Members of the Shura Council (Ahl Majlis al-Shura) in Islam: An Analytical Study towards the Members of the Malaysian Parliament
}

\author{
${ }^{1}$ Mohd Kamarul Amree Mohd Sarkam, ${ }^{1}$ Burhanuddin Jalal and ${ }^{1}$ Amnah Saayah Ismail
}

${ }^{1}$ Faculty of Defence Studies \& Management, National Defence University of Malaysia, Sungai Besi Camp, 57000 Kuala Lumpur, Malaysia.

Correspondence Author: Mohd Kamarul Amree Mohd Sarkam, Faculty of Defence Studies \& Management, National Defence University of Malaysia, Sungai Besi Camp, 57000 Kuala Lumpur, Malaysia.

Tel: +6019-3710995; E-mail: kamarul@upnm.edu.my

Received date: 12 January 2018, Accepted date: 20 June 2018, Online date: 2 July 2018

Copyright: (C) 2018 Mohd Kamarul Amree Mohd Sarkam et al. This is an open-access article distributed under the terms of the Creative Commons Attribution License, which permits unrestricted use, distribution, and reproduction in any medium, provided the original auth or and source are credited.

\begin{abstract}
The notion of 'good government' according to the Islamic principles cannot be isolated from the notion of 'good cooperation' because the efficiency of a government depends on the efficiency of its institutions and can only be realized through the meaningful cooperation of all in order to achieve similar ends. Thus, this conceptual paper will analyze the concept of the members of the Shura council in Islam, its features, the qualification of its members and to the extent how it can benefit the appointment of the members of the Malaysian Parliament. The members of the Malaysian Parliament are expected to secure the interests of the public, scrutinize the government policies, to ensure that the government remains accountable to all citizens and answerable for its actions and inactions. The question that arises at this point is whether the Members of the Malaysian Parliament could stand the way of Members of Shura council stand? Are the latter can infuse good elements to the former without any obstacles? Therefore, a systematic analytical study is highly needed in order to identify solutions to this matter which is based on two different fundamental perspectives and provides the basis for a subsequent evaluation of research findings with the aim to propose better solutions on this matter in the future.
\end{abstract}

Key words: institution; Democratic; Shura; respective; evaluation

\section{INTRODUCTION}

The term shura can be defined as the process of mutual consultation among groups of people in the decision making process. Same thing goes to the Malaysian Parliament in which it emphasises on the freedom of expression and thinking based on the existing differences in perception, mutual exchange of thoughts and opinions and eventually brings about the best conceivable result as all members of the decision making group are able to voice their opinions and benefit from the observations and insights of others. Since the Malaysian Parliament is part of the democratic institution, the original purpose of a parliament is the 'representation of the people as a whole'. This study assesses the compatibility of two important yet different political concepts, namely the Malaysian Parliamentary system and the mutual consultation (shura). It also aims to discuss the issue of members in the Malaysian Parliament in reference to the Islamic legal concept of shura. It is worth of notice at this point that the legal concept of shura is much more of a universal nature than that of the political principle which is admittedly quite a recent development. It can be concluded that some of the Malaysian Parliamentary technical procedures resemble the procedures and practices of mutual consultation. Thus, it can be considered legitimate to discuss and analyze the Members of the Malaysian Parliament in the context of shura, although both systems are very different in terms of their underlying ideology and conceptual framework.

Members of the Shura Council (Ahl Majlis al-Shura):

The Shura Council (Majlis as-Shura):

Badawi has identified six important reasons for the formation of Shura council which can be summarised as follows:

1. All political matters including legislation of the state's law cannot be imposed by one single individual; rather, it should be the responsibility of all citizens to accomplish this task.

2. Not every individual is eligible to serve as a member of the Shura Council; such position should be offered to qualified individuals in terms of their merit, knowledge and experience.

3. The principles of shura cannot be implemented except by a Shura Council.

4. The essential purpose of the Shura Council is to enjoin right and forbid wrong ('amr bi al-ma 'ruf wa nahi 'an al-munkar).

5. The formation of the Shura Council reflects the loyalty of the Muslim populace to their leaders.

6. The Sunnah of the Prophet Muhammad (s.a.w.) established the practice of mutual consultation (shura).

The success of such a Shura Council is based on the capability and sincerity of its members. However, the question that arises is who should become its members. What would be the criteria of membership? Should they be appointed through public election or nominated by a higher authority? And lastly, what are the responsibilities of a shura council's members? 


\section{The Qualifications of Shura Council Members:}

Muslim scholars have differed in their opinion of who should be the members of $a$ Shura council. Muslim authorities of the past stipulated that a member of a shura council should be an individual 'who is directly involved in the appointment of the community's leader after fulfilling the stringent qualifications and additional conditions, such as being recognised by the others'. Their approach to determine the members are related to their understanding of the term ahl alshura, different terms indicating different connotations. For instance, Hanafite jurists generally used the term al-'ashraf wa al-'ayan for those members of the shura council which elected the leader. Al-Qurtubi [1] quoted Ibn 'Atiyah who referred to them as 'ahl al-'ilm wa al-din. al-Mawardi [2] called them ahl al-hall wa al- 'aqd, al-Nawawi [3] al- 'ulama 'wa al-ru'asa' wa wujuh al-nas', and Abu Ya'la and Al-Baghdadi ahl al-ijtihad'.

More contemporary Muslim scholars developed their own distinctive connotation of members of a shura council, defining him as 'a qualified person who has been appointed to become the people's representative and to exercise certain powers, such as power of sovereignty, to appoint a leader, to preserve the state and the citizen's rights, etc'. This definition is kept quite general in terms of their function and responsibilities because it did not describe an actual institution, only the theoretical framework of such institution. Thus, such function could be exercise by any group of experts and distinguished individuals in the area of religion, military, science, law, etc.

At this point, the exact qualification of shura council members remains a matter of theoretical speculation. However, given the fact that this institution in question - if indeed realized - would occupy an important position in any Islamic government, the selection criteria would have to be set high. Special duties have to be entrusted to special people, and not everyone willing to assume such a position should be allowed to do so. The Qur'an contains a valuable teaching in this respect "Say: "Are those equal, those who know and those who do not know?". (The Qur'an, 39: 9).

There exists a striking difference between the one who is knowledgeable and the one who is ignorant. One can be entrusted with responsibility while the other cannot. One can exercise control and make informed decisions while the other cannot. Any responsibility in Islam is regarded as a trust (amanah) and part of worship ( 'ibadah). Individuals who are involved in the government service shoulder a huge responsibility because they are entrusted with the welfare of the public. They have to be among the most knowledgeable and competent of the community, so that they are capable of doing justice to their position.

When looking to historical precedents it can be observed that during Prophet Muhammad's (s.a.w.) lifetime, all of his trusted companions were eligible to give counsel. Sometimes he would consult with a large group of people and at other times just a selected few, such as Sa'ad Ibn 'Ubadah and Sa'ad Ibn Mu'adh in the story of Ghatafan [4]. On the other hand, 'Umar (r.a.) specifically appointed six companions of the Prophet (s.a.w.) as permanent members of his shura council. It appears that all of those companions who used to be consulted by the Prophet (s.a.w.) and with his two successors were considered the most eligible of people because of their character, piety, and wisdom.

Subsequent generations of Muslim jurists sought to determine the proper objective criteria for the selection of the members of $a$ shura council. The political theorist and advisor, al-Mawardi [2], for example, laid down a set of such qualifications in his famous al-'ahkam al-sultaniyyah applicable to the ahl al-hall wa al'aqd. Among their expected qualifications were as follows:

1. Moral probity and justice ('adalah); it referred to the upright character and integrity of an individual in the general sense, and to the adherence to piety as and absence of any conviction of criminal offense in the formal sense;

2. Knowledge ('ilm); eligible members had to be scholarly authorities, well-known for their expertise in their respective field, preferably the law;

3. Sound judgment and wisdom ( $r a^{\prime} y u$ wa hikmah).

Al-Maududi further explained that members of the shura council should possess knowledge of Islam, be well-versed in worldly affairs, and a generous state of mind which could relate to the diverse strata of society [5]. He further recommended that the shura council should be divided into legislative members and representative members. All legislative members had to be Muslim, male, adult, knowledgeable, and residents of the respective Islamic political entity. As for the second group, they had to be pious, knowledgeable, healthy, protective of the Shari'ah, and not practicing religious innovation ('ahl bid 'ah). (Al-Maududi, n.d.)

In this respect, Badawi offered is own modern set of qualifications. In his view, members of the shura council should be widely knowledgeable and experienced, well-versed in religious matters, pious, benevolent, and kind-natured. The last two characteristics are deemed necessary because a member of the shura council can only give good counsel if he harbours the best of intentions. He needs to offer his counsel respectfully and cultivate a good work environment of fruitful discussion and exchange of ideas.

Therefore, it can be concluded that the qualifications necessary for the members of any shura council may vary and may be applied differently in the present than they were applied in the past. However, there are certain criteria which are essential to it which cannot be altered or abolished at any circumstance, namely that of being a Muslim, maturity, knowledgeable, experienced, and of upright character. In fact, no position of power can be assumed legitimately in any Islamic government by any individual who does not fulfil these basic requirements of eligibility.

\section{The Malaysian Parliament and its Fundamental Principles:}

\section{The Malaysian Parliamentary Constituents:}

The sovereign state of Malaysia is governed by a parliamentary democratic system. It is based on the British Westminster model. As such, the Malaysian Parliament serves as a forum for the Malaysian public which has ceded the ultimate sovereignty to its parliamentary representatives [6]. It is worth noticing in this context that the Malaysian legal system has undergone many reforms which differentiate it from many other legal systems. The Malaysian Parliament was officially established on 31 August 1957 to replace the Federal Legislative Council introduced since the Federation of Malaya in 1948. The Malaysian Parliamentary constituents form part of the Federal legislature which consists of the Sovereign (Yang Di-Pertuan Agong) and two Chambers, the House of Senate (Upper House) and the House of Representatives (Lower House) (Article 44 of the Federal Constitution). Since Malaysia has opted for a modern parliamentary democratic system based on constitutional monarchy, it may be most appropriate at this point to briefly sketch the political role of the supreme head of state or Yang Di-Pertuan Agong:

\section{Yang Di-Pertuan Agong:}

The Yang Di-Pertuan Agong is the Head of State in Malaysia. He is the king as well as the Supreme Head of the Federation. According to the Malaysian constitution, the Yang Di-Pertuan Agong is given precedence over all other rulers in Malaysia. Moreover, as king he stands above everyone and can therefore not be convicted of any crime or be trialed in any court except the Special Court. (Article 32 (1). Similar to the British Westminster model, the Yang Di-Pertuan Agong is considered the Head of State while the elected Prime Minister is considered the Head of Government. As such, Malaysia shares the features of any other constitutional monarchy in contrast to absolute monarchies in which the monarch occupies the position of both Head of State and Head of Government [7]. Since Malaya's independence in 1957, the sovereignty of the Malay rulers remained specifically protected which makes its system of government unique because it combines the traditional element of hereditary kingship with modern democratic principles. The Yang Di-Pertuan Agong symbolises both the distinctively Muslim as well as Malay character of the federation.

\section{House of Senate (Dewan Negara):}

The House of Senate or Dewan Negara constitutes another important constituent in the Malaysian Parliament. Also known as the Upper House it can be considered as one of the highest bodies in the federal legislative structure. Its members are known as senators and prominent people distinguished in certain fields and professions. The Upper House plays an essential role in the parliamentary democracy system because its function is to debate and scrutinize the bills drawn up by the Lower House, as stated in the Reid Commission Report: "Our recommendations are made with the intention enabling the senate to become an influential forum of debate and discussion, and a body which will contribute valuable revision to legislation and which will be able to impose a measure of delay in exceptional cases" (Reid Commission Report, para. 64).

\section{House of Representatives (Dewan Rakyat):}

The important role of the House of Representatives or Dewan Rakyat is to propose, discuss and draw up new laws. Its members act as the true representative of the people or citizens. Due to the highly representative nature of the Lower House, the appointment of its members differs from that of the Dewan Negara. 
General elections held every five years determine which candidates become the representatives of the public and decide on public matters in parliament. Individuals sitting in the Dewan Rakyat chamber are expected to do their duties not to serve their own personal agendas and immediate interests or that of their parties but to serve the public and act in the best interest of the public in general [8].

\section{Analysis of Findings:}

After making an explanation about the shura council and the members of the Malaysian Parliament, the researcher intends to determine to which extent the shura principles can inspire adequate improvements to the members of the Malaysian Parliament. Below is presented a set of recommendations as stated above.

\section{The Method of Appointment:}

The legitimate method of appointing the members of a shura council has always been an important subject of speculative thought and enquiry about among Muslim jurists. Again, there exist no definite injunctions in this respect, neither in the form of recorded tradition nor according to historical precedent.

Many suggestions and recommendations have been made with regard to the appropriate method of appointment. Only one method will be discussed in further detail, namely the method of appointment through election. Although appointment by nomination constitutes another viable method of appointment, appointment by election has become the most common form of selection. The majority of Muslim countries are governed using democratic forms of government, albeit admittedly at a differing level of realization of truly democratic principles. Other Muslim countries are on the verge or in the process of democratizing their respective governmental institutions and constitutions.

The appointment through election requires a certain degree of democratic structure. Scholars have argued that the recorded Sunnah of the Prophet (s.a.w.) does contain a form of selection of representatives which resembles election. For instance, the Prophet (s.a.w.) requested the people of Madinah to select twelve representatives who would conclude the treaty with him on their behalf. [9]. The Prophet (s.a.w.) also reportedly asked the Muslim army to choose a man from amongst themselves who would take over the command if the existing commander died during battle. This also indicates that principle of election is resonant with the Shari'ah.

The Muslim political reformist al-Maududi [10] asserted that the practice of democratic election is permissible in Islam on the condition that it does not contain any prohibited and harmful elements, such as corruption, misuse of authority, and manipulation. This can be understood from his opinion when he said: In the case of election concerning the past and today, there are differences in terms of the ways of conducting an election process. It is impossible for Muslims nowadays to conduct an election process like that practiced during the early Islamic period due to the complexity of our societies today. It is permissible for us to utilize the method of conducting an election in response to our needs and wishes as long as it does not contradict Shari 'ah principles.

\section{The Responsibilities of the Members of a Shura Council:}

Again, there exists no established system which specifies the exact function of a shura council in Islamic political law and theory. It is thus a matter of ijtihad to determine and subsequently implement the said in order to suit the requirements of a given political setting. However, five general functions and responsibilities may be deduced from the nature of the very purpose of any shura council that can be infuse to the members of the Malaysian Parliament for the purpose of improvement:

\section{Choosing and Advising the Leader:}

The first responsibility of shura council members is to choose a political leader. The matter of choosing the community's leader falls under the duty of the capable few (fard al-kifayah). Barakah comments as follows: Muslim jurists have classified the act of choosing the leader as fard kifayah. As fard kifayah, it is not compulsory for all people to be involved in that matter, rather it is sufficient if some people who are eligible (like the members of the shura) to take part in order to fulfil the community's obligation. Besides that, to choose a good leader requires wise judgement, knowledge and experience, and the members of the shura must possess these characteristics. It should be added that they choose the leader not in order to enrich themselves but for the people because they are the people's representative.

The members of a shura council are expected to advise the leader in all arising matters of state. This reflects the fundamental function and purpose of the shura council itself which is strictly advisory. Advice also consists of admonition and is part of the public duty to enjoy the right and forbid the wrong evil (al'amr bi al-ma'ruf wa al-nahy 'an il-munkar).

\section{Executing the Law:}

Another important role of the shura council members is to execute the law. Here, the role of the shura council differs from that of the parliament in which only the Executive branch (Cabinet Ministers) can execute the law. The members of the shura council must oblige themselves to take part in formulating and executing the law.

The implementation of Islamic law should be an important agenda for the Islamic state. The proper application of Islamic law would relinquish all existing social problems which are menacing today's society.

\section{Serving the Public Interest:}

Since the members of such a council are appointed representatives of the people, they are entrusted with the task of making decisions which are in the best interest of the public in general. This trust is not to be taken lightly. Allah the Exalted warned mankind of not fulfilling their obligations, as stated in the following verse: "Allah does command you to render back your trusts to those whom they are due". (The Qur'an, 4: 58).

'Direct trust' here refers to the act of the shura council members of improving the people's living and working conditions, listening to the people's grievances, and offer solutions. 'Indirect trust' refers to the task of deliberating the problems and preparing recommendations to be brought in front of the shura council. When in session, the council members propose and debate over the issues in order to reach a decision which serves the public's best interests. Ibn Taymiyyah [11] insisted that it was the council's duty to act as the government's conscience by calling it to account (muhasabah). In any system of Islamic governance, the state's administration falls under the jurisdiction of shura.

Hence, the responsibility of shura members that is to serve the public. To fulfil the others' needs and to solve their problems constitute praiseworthy acts. A good deed does not benefit only one side but also ultimately benefits the person who does well to the benefit of others. Allah the Exalted will include them among the 'faithful people': "Whoever works righteousness, man or woman, and has faith, verily to him will We give a new life, a life that is good and pure and we will bestow on such their reward according to the best of their actions". (The Qur'an, 16: 97).

\section{Enthusiasm in Managing Tasks:}

Members of Shura and the parliament need to be disciplined and hardworking and determined in completing their assigned duties. Any Muslim woman's or man's motto should be reflecting the wisdom of spirit of the Prophet (s.a.w.) who said: "Work for this world as if you were to live forever and work for your Hereafter as if you were to die tomorrow". The members of the Parliament need to safeguard their intentions in order to protect themselves from corruptive influences. Although all the people's representatives were appointed to serve the public, ultimately they serve Allah and are accountable to Him: "Worship Allah as if you could see Him. Even though you are not able to see Him, verily, He sees you". (Sahih Muslim, Kitab al-Iman, Hadith No. 8).

\section{Protecting the Private Sphere:}

As all professionals, so do also members of Parliament need to balance between their responsibilities as public servants and those as who have families. The circumstance that they are elected representatives of the public makes it even more important that they give a good example in achieving this balance of public and private life without overexerting themselves or putting too much strain on their families. For example, women as the members of Parliament, their relation with their husband is required to be that of mutual trust and respect, especially since the husband needs to understand the demands his wife's work entails. Any female 
candidate for this political office should be aware of what such a position entails and how to cope with its demands. Family or marriage should not be sacrificed for a political career. In this respect, the Prophet (s.a.w.) is reported to have said: "Behold! Each one of you is a guardian, and each one of you will be asked about his subjects. A leader is a guardian over the people and he will be asked about his subjects; a man is a guardian over the members of his household and he will be asked about his subjects; a woman is a guardian over the members of the household of her husband and of his children, and she will be asked about them; a servant of a man is a guardian over the property of his master, and he will be asked about it. Behold! Each one of you is a guardian, and each one of you will be asked about his subjects". [12].

A women who pursue professional careers, be it in business or politics, have to be reminded that the same rules that apply to other women still apply to them as well. Equally to a Muslim man who serves the public, even in the position of president or prime minister, who is still required to fulfill his duties to his wife and children like any other man, so is a woman's duty as wife and mother still her duty, whether she be holding a public office or not. For example, most Muslim jurists agree that a Muslim woman may leave her house only with the permission of her husband if she wishes to earn Allah's blessings. If she does not do so, she may be able to go about her business yet her efforts will not be blessed by Allah and the Angels until she returns home.

\section{CONCLUSION:}

Seen from an Islamic perspective, the concept of mutual consultation (shura) can give benefit to the concept of parliament, an important element the governance. The application of shura at every administrative level ensures the true Islamic character of a government because mutual consultation was practiced by Prophet Muhammad (s.a.w.) and his successors, to the benefit of the Muslim community. Being a form of practice rather than a fixed institution, shura is a very flexible element which can be integrated into every decision-making process. It ensures that a selected group of qualified individuals are entrusted with exchanging and discussion their individual ideas with the intention to arrive at a consensus.

The Divine order to implement shura in the management of human affairs which are always communal affairs is unalterable and cannot be rejected or its implementation denied. Although mutual consultation may be exercised at a political level by a group of selected few, they do represent the most capable, knowledgeable and experienced members of society. Similarly, the elected members of parliament also represent society inasmuch as they were entrusted by the public to represent their interests. Although the institution of parliament and the shura council possess fundamental differences, in terms of qualification of members, an analysis can be made and highlighted. When incorporating the element of shura towards the members of the Malaysian Parliament, it can serve as starting point for infusing and cultivating Islamic norms and values into it. This allows a new perspective from which the present form of participation can be understood and encourage other people serving the purpose of their conscious adherence to the Shari 'ah principles.

\section{REFERENCES}

[1] Al-Qurtubi, Abu 'Abdullah Muhammad Ibn Ahmad, 1990. Al-Jami` li ’Ahkam al-Qur'an. Al-Qahirah: Matba'ah Dar al-Kutub. 4/249.

[2] Al-Mawardi, Abu Hasan 'Ali Ibn Muhammad Ibn al-Habib, 2006. Al-'Ahkam al-Sultaniyyah. ed. Ahmad Jad. Al-Qahirah: Dar al-Hadith, 21.

[3] Al-Nawawi, Zakariya Muhyiddin, 1987. Al-Minhaj. Beirut: Dar al-Kutub al-'Arabi, 78.

[4] Al-Ansari, 'Abdul Hamid Isma‘il, 1996. Al-Shura wa Atharuha fi al- Demoqratiyyah: Dirasah Muqaranah. Al-QÉhirah: Dar al-Fikr al- 'Arabi.

[5] Mahmud Shaltut, 1959. Al-Islam, 'Aqidah wa al-Shari'ah. Al-Qahirah: Al-'Idarah al-'Ammah li al-Thaqafah, 272.

[6] Lukman Thaib, 1994. Al-Shura (Political Representation in Islam) and its Application in the Contemporary Governmental System of the Republic of Pakistan and Malaysia. Selangor: Ph.D. thesis. National University of Malaysia.

[7] Mohd Salleh Abas, 1989. Parlimen Malaysia. Kuala Lumpur: Dewan Bahasa dan Pustaka.

[8] Chamil Wariya, 2009. Parlimen Malaysia: Perjalanan Badan Perundangan Persekutuan. Petaling Jaya: Media Global Matrix Sdn Bhd.

[9] Al-Bayati, Munir Hamid, 1979. Al-Dawlah al-Qanuniyyah wa al-Nizam al-Siyasi al-Islami. Baghdad: Dar al-“Arabiyyah, p: 254.

[10] Al-Maududi, Sayyid Abu al-'Ala, 1990. Nazariyah al-Islam wa Hadiy uhu. Beirut: Dar al-Fikr, 290.

[11] Ibn Taymiyyah, Taqi ad-Din Ahmad, 2000. Al-Siyasah al-Shar'iyyah fi 'Islah al-Ra'i wa al-Ra'yah. Beirut: Dar al-Sha'b, 39.

[12] Al-Bukhari, Muhammad Ibn Ismail Abu Abdullah, 1994. Bab al-`Itq. Hadith No. 733 